\title{
THE ENERGY DISSIPATION EFFECTS OF REDUNDANT MEMBERS IN SILOS UNDER EARTHQUAKES
}

\author{
Li Zhiming' and Geng Shujiang'
}

\begin{abstract}
SUMMARY
An analytical study is made of the response to strong base motion of reinforced concrete silo structures having energy dissipation redundant members. The structural model consists of an axisymmetric silo body supported by reinforced concrete columns. Analytical methods used include inelastic dynamic response history analysis, inelastic static analysis, and elastic modal spectral analysis (Building Code of China). The sensitivity of the structural parameters, such as the location of redundant members, relative linear stiffness, and reinforcement ratios, are examined for lateral force and ground motions. Based on the data presented, it is concluded that the advantages of energy dissipation redundant members are of ensuring yielding hinges occur in selected elements, improving the distribution of internal forces, and providing increased ductility. Numerical examples are discussed to show the apnlication potential.
\end{abstract}

\section{INTRODUCTION}

Silos are widely used as industrial constructions for storage, conveyance and transportation in steel manufactories or mine corporations. During Hai Cheng city earthquake (1975) and Tang-Shan city earthquake (1976), about ninety percent of the silo structures were damaged in varying degrees (Fig. 1).

Earthquake investigations $(1,2)$ have shown that the concrete cracking and crushing at the top of columns and reinforcement buckling caused major damage and sometimes even collapse. Because of the special features of silo structures, such as the storage of heavy materials, abrupt stiffness changes at the column to silo body joint, the small number of structural elements and low level of redundancy, the safety factor for lateral resistance against seismic forces was limited. In addition, the special limitations imposed by the production processes involving the silos gave designers and owners no way of increasing the earthquake resistance by the usual methods, such as using shear walls or by bracing the columns. The objective of this study was to determine a suitable type of silo structure that would have an improved level of lateral resistance against seismic loads.

In line with the concept of "structural fuses" (3) and "strong column-weak team"

(1) Research Engineer, Aseismic Engineering Department, Central Research Institute of Building \& Construction, Ministry of Metallurgical Industry, P.R. China

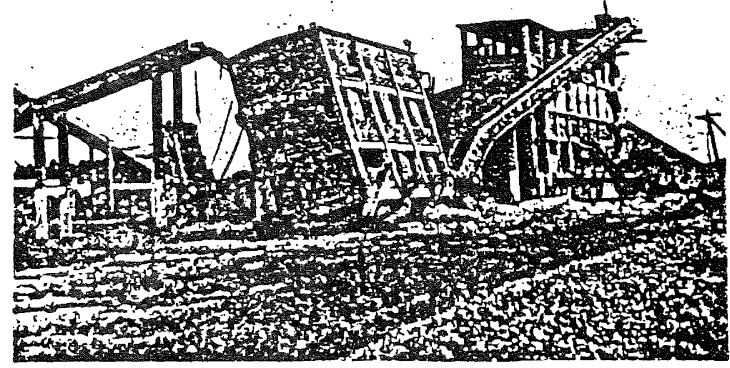

FIG. 1 - SILO COLUMN DAMAGE

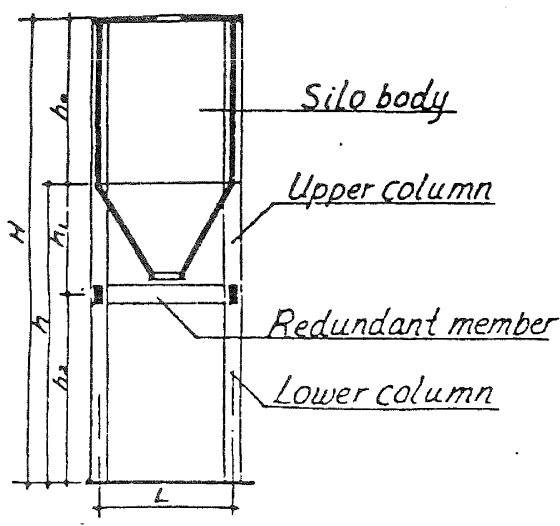

FIG. 2 - CROSS-SECTION OF SILO 
design considerations (4), a weaker beam below the silo body was used as a redundant member for dissipating seismic energy so that the safety of the supporting columns during earthquakes and normal service loading could be guaranteed. A study was carried out for a range of values for the key parameters and the general characteristics of the internal force distribution, the behaviour and ductility improvement of the silo structure with redundant members under the lateral loading and ground motions are presented in this paper.

\section{COMPUTATIONAL MODEL AND DIFFERENTIAL} EQUATIONS FOR THE PROBLEM

The computational model has been assumed to be a two mass system, being the silo body and the redundant member. Under the application of horizontal forces the rigid silo body was considered to be able to displace and rotate in its own plane.

Using Lagrange's equation, the system of differential equations for the action of horizontal dynamic forces on the complete structure is, in matrix form:

$[\mathrm{M}]\{\ddot{\mathrm{U}}\}+[\mathrm{C}]\{\dot{\mathrm{U}}\}+[\mathrm{K}]\{\mathrm{U}\}=\{\mathrm{P}\}$
in which $[\mathrm{M}]=\left[\begin{array}{lll}\mathrm{m} / 3 & \mathrm{sym} \cdot \\ \mathrm{m} / 6 & \mathrm{~m} / 3 & \\ 0 & 0 & \mathrm{~m}_{1}\end{array}\right]$, the mass

matrix; $[\mathrm{C}]=$ damping matrix: $[\mathrm{K}]=$ stiffness matrix; $\{\mathrm{P}\}=$ generalized load vectors; and $\{\ddot{U}\},\{\tilde{U}\},\{U\}=$ acceleration, velocity and displacement vectors. The rotational coupling effects of the rigid body was included in the stiffness matrix [K] and the mass matrix [M] of Eq. (1), and the effects of bending, shear and axial force on the stiffness coefficients were considered as well. obviously, this analytical model would be more accurate than the normal MDOF or SDOF system (Fig. 3(a)) in which only translational motion of the silo body was taken into account.

\section{ANALYTICAL METHODS AND PROCEDURE}

Three analytical methods were used in this study: (1) Elastic modal spectral analysis (according to Building code of China (5)): (2) Inelastic static analysis: and (3) Inelastic dynamic response history analysis, designated analyses $A, B$ and $C$, respectively. The following parameters were varied in the study:

(1) Location coefficient of redundant member $\left(\rho=h_{1} / h\right)$;

(2) Relative linear stiffness ratio of redundant member to column ( $\alpha=$ $\mathrm{J}_{\mathrm{b}} \mathrm{h} / \mathrm{J}_{\mathrm{C}} \mathrm{L}$ ); and

(3) Reinforcement ratio of redundant member $\left(\mu_{g}=A_{g} / b h_{b}^{\prime}\right)$.

For analysis A, internal force differences between the cases with and without redundant members were described, and the upper and lower bound of key parameters $\rho$ and $\alpha$ were determined for the reasonable state of supporting columns. In this case, two basic parameters, earthquake intensity scale and site soil category, were equal to E.I.S $=9$ and type 2 , respectively.

Table 1 shows the resulting values of column end moment reduction factor. The top moment of the upper column reduces by $26.1-50.3 \%$, top of the lower column by $11.8-53.4 \%$, and the bottom moment of the upper column by 43-96.4\%. Clearly, it is more beneficial to have silo structures with redundant members than without them.

It should be pointed out that the trends for column end moment reduction are presented for changes of $\rho$ and $\alpha$. In this study, two factors were required, i.e. (1) sufficient length of upper column preventing short column damage; and (2) sufficient stiffness of the redundant member to absorb as much seismic energy as possible. After general consideration, the optimum range of values of $\rho=0.2-0.4$ and $\alpha=1.7-2.55$ were adopted.
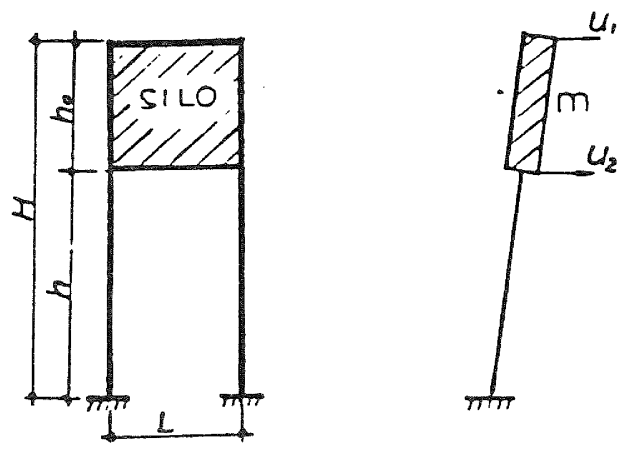

(a) WITHOUT REDUNDANT ME:ABER
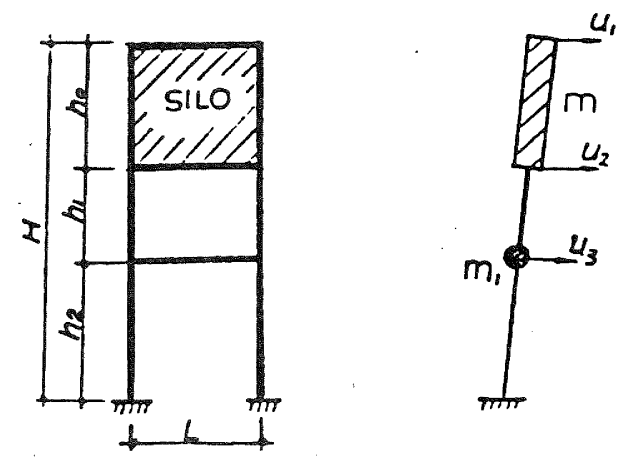

(b) WITH REDLNDANT MEMMBER 
TABLE 1 - THE REDUCTION FACTOR OF COLUMN END MOMENT (은

\begin{tabular}{|c|c|c|c|c|c|c|c|c|c|c|c|c|}
\hline \multirow{3}{*}{$\begin{array}{l}\text { Location } \\
\text { of } \\
\text { redundant } \\
\text { member } \\
\rho\end{array}$} & \multicolumn{3}{|c|}{$\begin{array}{c}\text { Top moment } \\
\text { of } \\
\text { upper col. } \\
\text { ut } \\
R_{C}\end{array}$} & \multicolumn{3}{|c|}{$\begin{array}{c}\text { Bottom moment } \\
\text { of } \\
\text { upper col. } \\
\mathrm{ub}_{\mathrm{C}}\end{array}$} & \multicolumn{3}{|c|}{$\begin{array}{c}\text { Top moment } \\
\text { of } \\
\text { lower col. } \\
\text { lt } \\
R_{C}\end{array}$} & \multicolumn{3}{|c|}{$\begin{array}{c}\text { Bottom moment } \\
\text { of } \\
\text { lower col. } \\
R_{\mathrm{C}} \mathrm{b}\end{array}$} \\
\hline & \multicolumn{3}{|c|}{$\alpha$} & \multicolumn{3}{|c|}{$\alpha$} & \multicolumn{3}{|c|}{$\alpha$} & \multicolumn{3}{|c|}{$\alpha$} \\
\hline & 1.00 & 1.70 & 2.55 & 1.00 & 1.70 & 2.55 & 1.00 & 1.70 & 2.55 & 1.00 & 1.70 & 2.55 \\
\hline $\begin{array}{l}0.1 \\
0.2 \\
0.3 \\
0.4\end{array}$ & $\begin{array}{l}29.6 \\
33.9 \\
29.6 \\
21.8\end{array}$ & $\begin{array}{l}39.8 \\
44.1 \\
37.2 \\
26.1\end{array}$ & $\begin{array}{l}46.4 \\
50.3 \\
41.6 \\
28.4\end{array}$ & $\begin{array}{l}43.0 \\
70.4 \\
92.7 \\
86.1\end{array}$ & $\begin{array}{l}51.9 \\
80.9 \\
96.4 \\
74.7\end{array}$ & $\begin{array}{l}57.5 \\
86.9 \\
90.3 \\
68.1\end{array}$ & $\begin{array}{l}18.3 \\
28.0 \\
39.1 \\
53.4\end{array}$ & $\begin{array}{l}14.3 \\
20.8 \\
29.3 \\
41.9\end{array}$ & $\begin{array}{l}11.8 \\
16.5 \\
23.4 \\
35.0\end{array}$ & $\begin{array}{r}-2.0 \\
-2.9 \\
-2.2 \\
1.1\end{array}$ & $\begin{array}{l}-3.0 \\
-4.5 \\
-4.1 \\
-0.1\end{array}$ & $\begin{array}{l}-3.8 \\
-5.7 \\
-5.5 \\
-0.2\end{array}$ \\
\hline
\end{tabular}

Note: A positive value indicates a reduction, and a negative value an increase.

With analysis $B,(1)$ the action of long-term loads and lateral monotonic loads; (2) the overturning effects of lateral loads; (3) the effects of stiffness degeneration after cracking and hinging on the columns and beams; and (4) the internal forces redistribution when structure reaches the plastic stage; were taken into account. During the analysis process, the location parameter $\rho$, relative linear stiffness ratio $\alpha$ and steel ratio $\mu$ were continually adjusted until hinging occurred in the redundant member.

Plots of the relationship between force and displacement and the corresponding ductility reduction coefficient are presented in Figs. 4 and 5 . The relationship shows (1) the silo without redundant members has lowest alues of ductility and yield loads; (2) the silo with redundant members designed as weaker elements behaves excellently for both indexes mentioned above; and (3) the behaviour of the silo with redundant members not designed as weaker elements lies between that for (1) and (2).

For the purpose of guaranteeing that yielding hinges occur in selected elements during earthquakes, it is necessary to choose the parameters $\rho, \alpha$ and $\mu$ (shown in Fig. 6, so that the reinforcement detailing will permit the first hinge to form there.

With analysis $C$, an examination was carried out of whether the ductility of silo structures would satisfy the ductility demand of practical ground motions. For this study, adopting a story-hysteresis model and inputting 20 artificial earthquake records (according to Building Code of China, E.I.S $=9$ and 9 ; site soil category = type $2)$, the resulting values of average displacement ductility were obtained as shown in Table 2 .

Table 2 shows the ductility of redundant

TABLE 2 - COMPARISONS OF DUCTILITY COEFFICIENT

\begin{tabular}{|c|c|c|c|c|c|c|c|c|c|c|c|c|c|}
\hline \multirow{5}{*}{$\rho$} & \multicolumn{3}{|c|}{$\begin{array}{c}\text { Without redundant } \\
\text { member }\end{array}$} & \multicolumn{9}{|c|}{$\begin{array}{c}\text { With redundant } \\
\text { member }\end{array}$} & \multirow{5}{*}{ Note } \\
\hline & & $\alpha=$ & .00 & & $\alpha=1$ & & & $\alpha=1$ & & & $\alpha=$ & 55 & \\
\hline & \multirow{3}{*}{ Cs } & C & & \multirow{3}{*}{ Cs } & $\mathrm{Cc}$ & & \multirow{3}{*}{$\mathrm{Cs}$} & $\mathrm{Cd}$ & & \multirow{3}{*}{$\mathrm{Cs}$} & \multirow{2}{*}{\multicolumn{2}{|c|}{$\frac{C d}{\text { E.I.S. }}$}} & \\
\hline & & \multicolumn{2}{|c|}{ E.I.S. } & & \multicolumn{2}{|c|}{ E.I.S. } & & \multicolumn{2}{|c|}{ E.I.S. } & & & & \\
\hline & & 8 & 9 & & 8 & 9 & & 8 & 9 & & 8 & 9 & \\
\hline $\begin{array}{l}0.0 \\
0.1 \\
0.1 \\
0.2 \\
0.3 \\
0.4\end{array}$ & 1.03 & 0.90 & 6.30 & $\begin{array}{l}2.08 \\
2.15 \\
2.29 \\
2.43 \\
2.75\end{array}$ & $\begin{array}{l}0.81 \\
0.91 \\
0.81 \\
0.80 \\
0.78\end{array}$ & $\begin{array}{l}6.53 \\
2.22 \\
2.22 \\
2.21 \\
1.94\end{array}$ & $\begin{array}{l}1.65 \\
2.17 \\
2.32 \\
2.40 \\
2.55\end{array}$ & $\begin{array}{l}0.74 \\
0.90 \\
0.81 \\
0.82 \\
0.75\end{array}$ & $\begin{array}{l}4.56 \\
2.23 \\
2.22 \\
0.32 \\
1.86\end{array}$ & $\begin{array}{l}1.62 \\
2.17 \\
2.21 \\
2.18 \\
2.36\end{array}$ & $\begin{array}{l}0.87 \\
0.76 \\
0.78 \\
0.76 \\
0.72\end{array}$ & $\begin{array}{l}1.90 \\
2.62 \\
2.21 \\
2.01 \\
1.76\end{array}$ & $\begin{array}{l}* \\
* * \\
* * \\
* * \\
* *\end{array}$ \\
\hline
\end{tabular}

Note: *_ redundant member not designed as weaker element

**__ redundant member designed as weaker element;

Cs- the ductility coefficient of silo (by analysis B)

Cd- the ductility demand during an earthquake (by analyis $C$ ). 

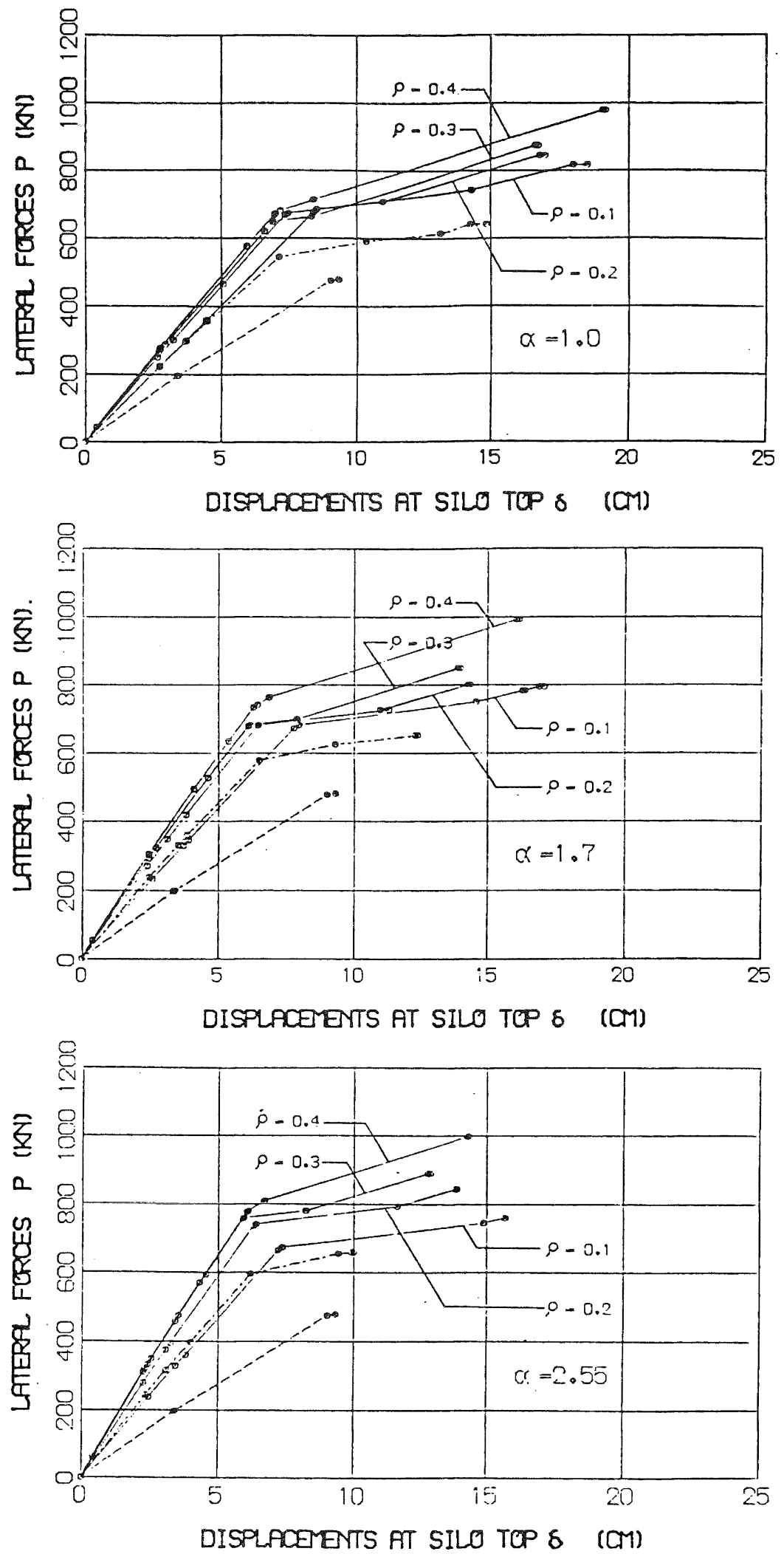

Note: ---- With redundant member designed as a weaker element -...- With redundant member not designed as a weaker element

FIG. 4 - RELATIONSHIP BETWEEN FORCE AND DISPLACEMENT FOR $\alpha=1.0$ (top), $\alpha=1.7$ (middle) and $\alpha=2.55$ (bottom) 
member designed on weaker element consideration meets the earthquake ductility demand (E.I.S $=9$ ) over the range of values $\rho=$ $0.2-0.4$.

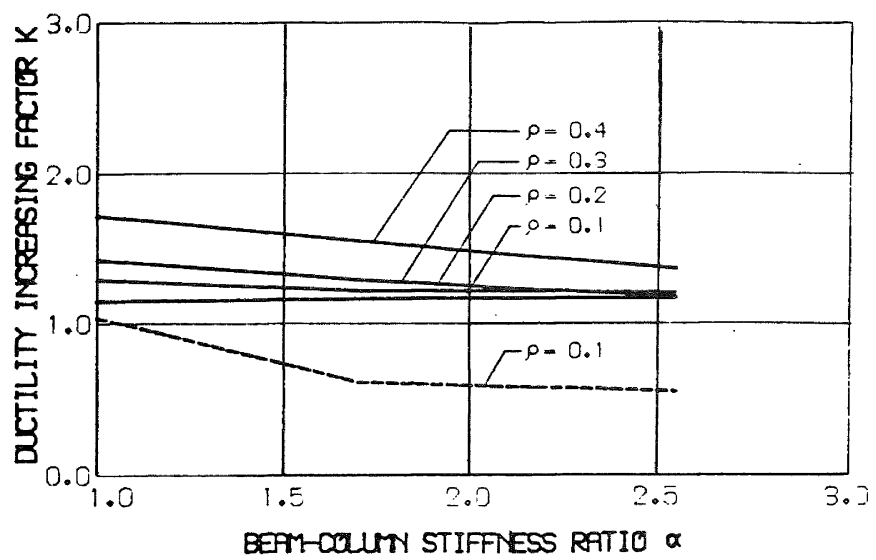

FIG. 5 - DUCTILITY REDUCTION COEFFICIENT

\section{NUMERICAL EXAMPLES}

In this study, three practical engineering examples are presented: (1) a silo for a magnesium mine (in Hai Cheng city) without redundant members; (2) a silo for coal storage (in Tang Shan city) with redundant members which were not designed as weaker elements; and (3) a coal mine silo (in Tang Shan city)

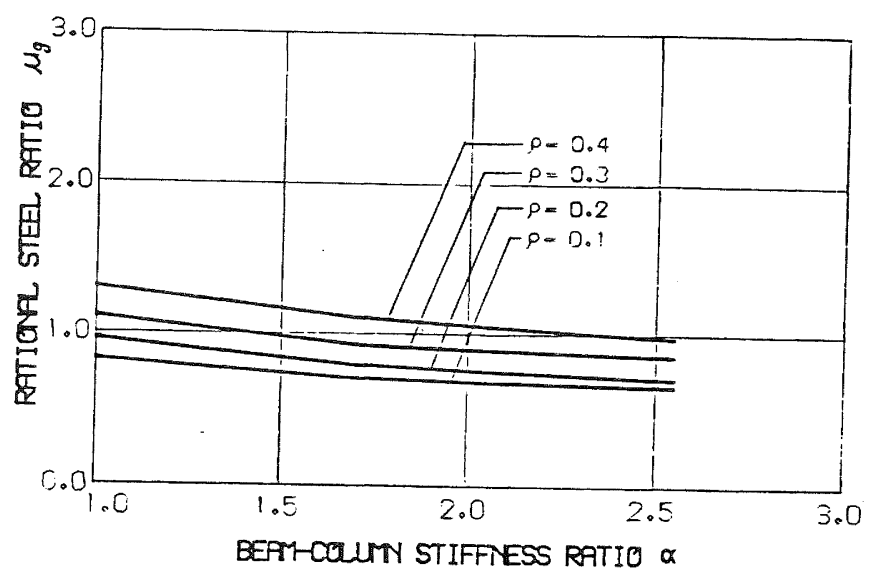

FIG. 6 - RATIONAL REINFORCEMENT RATIO

with redundant members designed as weaker elements. The area in which these were located was E.I.S $=0$ and site soil = type 2. These silos were of similar column height, column cross-section and beam length, as shown in Table 3 and Fig. 2 .

The actual earthquake damage sustained by these three buildings is summarised in Table 4 , along with the actual ductility of the silos and the ductility demand

\section{TABLE 3 - DATA FOR ANALYTICAL EXAMPLES}

\begin{tabular}{|c|c|c|c|c|c|c|c|c|c|}
\hline $\begin{array}{l}\text { Desig- } \\
\text { nation }\end{array}$ & $\begin{array}{c}\text { Height } \\
\text { of } \\
\text { silo } \\
\text { body } \\
\text { h } \\
\text { (m) }\end{array}$ & $\begin{array}{l}\text { Height } \\
\text { of } \\
\text { upper } \\
\text { col. } \\
\text { h } \\
\text { (m) }\end{array}$ & $\begin{array}{l}\text { Height } \\
\text { of } \\
\text { lower } \\
\text { col. } \\
\text { h } \\
(\mathrm{m})\end{array}$ & $\begin{array}{l}\text { Whole } \\
\text { height } \\
\text { of } \\
\text { col. } \\
\text { h } \\
\text { (m) }\end{array}$ & $\begin{array}{l}\text { Whole } \\
\text { height } \\
\text { of } \\
\text { silo } \\
\text { H } \\
\text { (m) }\end{array}$ & $\begin{array}{l}\text { Length } \\
\text { of } \\
\text { red. } \\
\text { mem. } \\
\text { L } \\
\text { (m) }\end{array}$ & $\begin{array}{c}\text { Cross } \\
\text { sec. } \\
\text { of } \\
\text { col. } \\
\text { (cm) }\end{array}$ & $\begin{array}{c}\text { Cross } \\
\text { sec. } \\
\text { of } \\
\text { red. } \\
\text { mem. } \\
(\mathrm{cm})\end{array}$ & $\begin{array}{l}\text { Load } \\
\text { on } \\
\text { one } \\
\text { col. } \\
(t)\end{array}$ \\
\hline $\begin{array}{l}(1) \\
(2) \\
(3)\end{array}$ & $\begin{array}{l}5.80 \\
5.40 \\
5.40\end{array}$ & $\begin{array}{l}3 . \overline{.00} \\
4.20\end{array}$ & $\begin{array}{l}\overline{7.60} \\
6.60\end{array}$ & $\begin{array}{l}10.40 \\
10.60 \\
10.80\end{array}$ & $\begin{array}{l}16.20 \\
16.00 \\
16.20\end{array}$ & $\begin{array}{l}6.00 \\
7.00 \\
7.00\end{array}$ & $\begin{array}{l}70 * 70 \\
70 * 70 \\
70 * 70\end{array}$ & $\begin{array}{l}--- \\
40 * 75 \\
40 * 90\end{array}$ & $\begin{array}{l}170 \\
180 \\
180\end{array}$ \\
\hline
\end{tabular}

TABLE 4 - SUMMARY OF ANALYSIS RESULTS AND SEISMIC DAMAGE INVESTIGATIONS

\begin{tabular}{|c|c|c|c|c|}
\hline $\begin{array}{l}\text { Example } \\
\text { No. }\end{array}$ & $\begin{array}{l}\text { Ductility of } \\
\text { Silo } \\
\text { Cs }\end{array}$ & $\begin{array}{l}\text { Ductility } \\
\text { demand of } \\
\text { earthquake } \\
\qquad \text { cd }\end{array}$ & Analysis results & $\begin{array}{l}\text { Seismic damage } \\
\text { investigations }\end{array}$ \\
\hline (I) & 1.06 & 4.36 & $\begin{array}{l}\text { Reinforcement and ductility } \\
\text { were not satisfied }\end{array}$ & $\begin{array}{l}\text { Concrete crushing } \\
\text { at the column top } \\
\text { end, reinforcement } \\
\text { buckling }\end{array}$ \\
\hline (2) & 2.07 & 2.40 & $\begin{array}{l}\mu g=1.2 \% \text { (exceeds the } \\
\text { optimum range of rein- } \\
\text { forcement) } \rho=0.28, \\
\alpha=1.00(<1.70-2.55)\end{array}$ & $\begin{array}{l}\text { Concrete crushing } \\
\text { at some lower } \\
\text { column top ends. }\end{array}$ \\
\hline (3) & 2.36 & 2.30 & $\begin{array}{l}\rho=0.39, \alpha=1.87 \\
\mu g=1.06 \% ; \text { all three key } \\
\text { parameters meet the } \\
\text { requirements of this study. }\end{array}$ & $\begin{array}{l}\text { Tiny horizontal } \\
\text { craiss at the lower } \\
\text { column top erd; the } \\
\text { ends of redundant } \\
\text { members were damaged } \\
\text { in } \rightarrow h n n\end{array}$ \\
\hline
\end{tabular}


required by the earthquakes used in the analyses. The ductility differences and the influence of the redundant members in reducing the seismic damage can be seen.

\section{CONCLUSIONS}

A rational method of designing the redundant members as a weaker element to dissipate the seismic energy has been suggested to improve the ductility of silo structures.

In view of the results presented, the following conclusions are offered:

1. The redundant members have the effect of improving internal force distribution.

2. By designing redundant members as weaker elements, the ductility of the silo structures and the dissipation of seismic energy have been increased.

3. Three key parameters, which make full use of redundant members have been varied over the ranges of $\rho=0.2-0.4$, $\alpha=1.70-2.55$ and $\mu \mathrm{g}$ as shown in Eig. 6 .

\section{REFERENCES}

(1) "Report: The Silo Damages in Tang Shan Earthquake", 1977. (In Chinese).

(2) "Seismic Damage Investigation Report of Metallurgical Constructions in Hai Cheng Earthquake" 1975. (In Chinese).

(3) Mark Fintel and S.K. Ghosh, "The Structural Fuse: An Inelastic Approach to Seismic Design of Buildings". Div. of Civil Engineering, ASCE, Jan. 1981.

(4) Hu Qingchang, "The Seismic Design for Some Reinforced Concrete Buildings". Proc. of Earthquake and Hazard Engineering, 1986. (In Chinese).

(5) "Building Code of China, 1985", Building Industry Press, Peking, China. 